\title{
Kilka uwag o potrzebie zachowania spójności pomiędzy prawem karnym a innymi dziedzinami prawa
}

\begin{abstract}
The principle of subsidiarity of criminal law requires the location of the norms which regulate specific social relations beyond the branch of law which was adduced. On the one hand, it enables the realisation of the postulate, peculiar to the system of repressive law, to place the rules of conduct and the norms which regulate specific relations beyond criminal law. On the one hand, the intervention with criminalisation into relations regulated by other branches of law should enforce a significant synchronisation of the regulations of criminal law with the norms which are peculiar to a given branch of law. A legal system which features co-relations should represent consistency. As a result, the criminalisation of behaviour regulated by other branches of law deepens the connotations between them. The enracinement of legal regulations into an increasing number of new areas is the source of doubts associated with the lack of consistency between the particular regulations or, in the case of a strong drive of the criminal law to inscribe itself into legal norms which regulate a given sphere of life, to the negation of the capability of the criminal law to acquire functions which are set to this branch of law. On the basis of selected examples, the article attempts to reflect upon the legislator's maintenance of the balance between these values.
\end{abstract}

Key words: The subsidiarity of criminal law, criminal law and other branches of law

System prawny, rozumiany jako zbiór elementów o pewnych cechach, między którymi występują określone współzależności ${ }^{1}$, powinien cechować się pewną jednolitością ${ }^{2}$. Potrzeba uporządkowania systemu prawnego doprowadziła do wyodrębniania w jego ramach gałęzi prawa. W prawoznawstwie podkreśla się, że pretendującymi do miana uniwersalnych

${ }^{1}$ Tak J. Nowacki, Z. Toвor: Wstęp do prawoznawstwa. Kraków 2000, s. 108.

${ }^{2}$ W. LANG, J. WróblewsKI, S. ZaWAdzKI: Teoria państwa i prawa. Warszawa 1979, s. 349. 
kryteriów klasyfikacyjnych $\mathrm{w}$ zakresie rozgraniczania i ustalania relacji między poszczególnymi dyscyplinami naukowymi są: kryterium przedmiotu lub (i) kryterium metody badawczej ${ }^{3}$. O ile nietrudno przypisać określony wycinek życia społecznego prawu podatkowemu, rolnemu czy ochronie środowiska, to $\mathrm{w}$ przypadku prawa karnego rzecz przedstawia się odmiennie. Od wielu lat cechy charakterystycznej tejże dziedziny prawa upatruje się w braku samodzielnej organizacji jakiegokolwiek wycinka życia społecznego, tj. nienormowaniu żadnego obszaru we własnym zakresie $^{4}$. Za drugi istotny wyróżnik prawa karnego podaje się zasadę subsydiarności, zgodnie z którą prawo karne powinno być stosowane w ostateczności, gdy inne dziedziny nie dysponują środkami wystarczającymi dla przeciwdziałania zachowaniom mogącym wyrządzić szkodę dobrom prawnym ${ }^{5}$. Widoczna jest tym samym pewna wtórność prawa karnego względem innych dziedzin prawa. Jest ona nazywana zasadą konieczności sankcji karnej, według której dla wprowadzenia kryminalizacji określonego typu czynu zabronionego konieczne jest uprzednie przesądzenie, że odpowiedzialność cywilnoprawna lub administracyjna nie jest wystarczająca $^{6}$. Jeżeli jakieś zachowanie, właściwe dla określonej dziedziny życia, nie jest sprzeczne z normami prawnymi ją charakteryzującymi, tym bardziej nie może ono zostać uznane za zabronione pod groźbą kary przez prawo karne ${ }^{7}$.

Wypełnienie reguły ultima ratio prawa karnego wymaga co do zasady, aby czyny zabronione pod groźbą kary zostały uznane za bezprawne również w przepisach regulujących konkretną dziedzinę prawa, której dotyczyć ma norma sankcjonowana. To zaś wymusza zachowanie harmonii pomiędzy określonymi typizacjami przewidzianymi przez prawo karne a innymi dziedzinami prawa. Trudno zanegować stwierdzenie, że racjonalny ustawodawca powinien dążyć do spójności wewnątrzsystemowej, albowiem niedopuszczalne jest stosowanie regulacji karnych do zacho-

${ }^{3}$ L. Bogunia, T. Kalisz: Pojęcie i nauka prawa karnego wykonawczego. Uwagi na tle procesu wyodrębniania dyscyplin naukowych prawoznawstwa. W: Problemy wymiaru sprawiedliwości karnej. Księga jubileuszowa Profesora Jana Skupińskiego. Red. A. BŁaChNIo-Parzych et al. Warszawa 2013, s. 574.

${ }^{4}$ Por. L. Tyszkiewicz. W: Prawo karne. Część ogólna, szczególna i wojskowa. Red. T. DuKIET-NagórsKa. Warszawa 2016, s. 26-27.

5 Zob. O. GóRnIOK: Znaczenie subsydiarności prawa karnego $w$ jego interpretacji. PiP 2007, z. 5, s. 49.

${ }^{6}$ Por. M. Królikowski, R. ZawŁocki: Prawo karne. Warszawa 2015, s. 48.

${ }^{7}$ W. Wróbel, A. Zoll: Polskie prawo karne. Czesść ogólna. Kraków 2010, s. 25-26.

${ }^{8}$ Zob. W. WróbeL: Czy powrót do racjonalizmu? Projekty nowelizacji Kodeksu karnego $w$ perspektywie zmian dokonanych $w$ prawie karnym $w$ latach 2005-2007. W: Populizm penalny $i$ jego przejawy w Polsce. Red. Z. Sienkiewicz, R. Кокот. Wrocław 2009, s. 104. 
wań dozwolonych w innych regulacjach prawnych ${ }^{9}$. Subsydiarność prawa karnego oraz zasada spójności porządku prawnego obowiązującego w danym państwie musi zakładać respektowanie norm tych gałęzi prawa, które mają za zadanie organizować daną dziedzinę życia społecznego. Oznacza to, że zarówno na etapie stanowienia prawa, jak i jego stosowania zachodzi potrzeba budowania modelu prawa karnego w taki sposób, aby zachować harmonię z regulacjami przewidzianymi przez inne dziedziny prawa. Z drugiej jednak strony dążenie za wszelką cenę do koherentności nie może odbywać się ze szkodą dla wypełnienia funkcji stawianych przed różnymi gałęziami przepisów. Czasami zachowanie monolitowego systemu po prostu nie jest możliwe, ponieważ nie pozwalają na to rozbieżne zadania, które konkretne przepisy mają wypełnić.

Tytułem przykładu - o ile w prawie karnym za jedną z naczelnych reguł uznaje się zasadę odpowiedzialności osobistej, rozumianą jako konieczność poniesienia negatywnych konsekwencji wynikających z popełnionego przestępstwa jedynie przez osobę, która czynu takiego się dopuściła $^{10}$, w prawie cywilnym rzecz nie jest już tak oczywista. Jeżeli dojdzie do zgonu skazanego, jego spadkobiercy nie odbędą wymierzonej kary pozbawienia wolności sprawcy przestępstwa. Na gruncie przepisów prawa cywilnego rzecz przedstawia się już nieco inaczej. Ponoszenie przez spadkobierców przestępcy konsekwencji wynikających z czynu zabronionego jest zależne od ich rodzaju. O ile w skład spadku nie wchodzi obowiązek zapłaty grzywien i kar pieniężnych orzeczonych za życia spadkodawcy, to roszczenie o naprawienie szkody i odpowiadający mu $\mathrm{z}$ tego tytułu obowiązek zasadniczo są dziedziczone ${ }^{11}$. Rozbieżność ta jest jednak uzasadniona odmiennością funkcji stawianych prawu karnemu i cywilnemu. O ile bowiem w prawie spadkowym $\mathrm{z}$ momentem otwarcia spadku dochodzi do sukcesji uniwersalnej, tj. do wejścia (co do zasady) przez spadkobiercę w ogół praw i obowiązków spadkodawcy, to w prawie karnym jako naczelną zasadę formułuje się brak możliwości przenoszenia na podmioty trzecie odpowiedzialności za popełnione przestępstwie. W konsekwencji wskazana powyżej różnica zasługuje na akceptację. Pytanie jednak, czy w prawie karnym nie można znaleźć instytucji, które nie uwzględniają w stopniu wystarczającym regulacji przewidzianych w innych dziedzinach prawa, a rozbieżności tych nie da się wytłumaczyć odrębnością funkcji formułowanych przed poszczególnymi gałęziami.

\footnotetext{
${ }^{9}$ Tak S. ŻóŁtek: Prawo karne gospodarcze $w$ aspekcie zasady subsydiarności. Warszawa 2009, s. 168.

${ }^{10}$ W. Wróbel, A. Zoll: Polskie prawo karne..., s. 411-422.

11 M. Pazdan. W: Kodeks cywilny. T. II: Komentarz do artykułów 450-1088. Red. K. Pietrzykowski. Warszawa 2005, s. 878 i 888.
} 
Jednym z przykładów kluczowych praw chronionych przez prawo cywilne jest własność. Prawo to zostaje poddane szerokiej ochronie, począwszy od aktów najwyższej rangi. Konstytucja RP stanowi w art. 21 ust. 1, że Rzeczpospolita Polska chroni własność i prawo dziedziczenia. Z kolei według art. 64 ust. 1 Konstytucji każdy ma prawo do własności, innych praw majątkowych oraz prawo dziedziczenia. Przepis ten jest rozwijany w dalszych ustępach, mianowicie własność, inne prawa majątkowe oraz prawo dziedziczenia podlegają równej dla wszystkich ochronie prawnej (ust. 2), natomiast własność może być ograniczona tylko w drodze ustawy i tylko w zakresie, w jakim nie narusza istoty prawa własności (ust. 3).

Powstaje zatem pytanie, czy niektóre z norm należących do szeroko rozumianego prawa karnego nie ograniczają prawa własności w stopniu nadmiernym, a jednocześnie nieuzasadnionym funkcjami szeroko rozumianego prawa karnego, doprowadzając do niekompatybilności między prawem karnym a przepisami regulującymi daną gałąź prawa.

Jedną z norm, która może budzić wątpliwości w tym zakresie, jest art. $43 \mathrm{~h} \$ 3$ k.k.w. W myśl powyższego przepisu, jeżeli skazany zamieszkuje wspólnie z inną osobą lub osobami pełnoletnimi, warunkiem rozpoczęcia dozoru stacjonarnego jest uprzednia pisemna zgoda tych osób złożona do sądu, obejmująca także umożliwienie podmiotowi dozorującemu przeprowadzanie czynności kontrolnych. Dopełnieniem tego przepisu jest art. 43la § 1 k.k.w., który jako jeden z warunków odbycia kary w systemie dozoru elektronicznego podaje w pkt 4 wymóg wyrażenia przez osoby pełnoletnie zamieszkujące wspólnie ze skazanym ww. zgody. Oznacza to, że brak zgody dorosłych domowników ogranicza możliwość odbywania kary w systemie dozoru elektronicznego, chyba że wykonanie kary w takim systemie $\mathrm{w}$ sposób oczywisty nie wiąże się z nadmiernymi trudnościami dla osoby, która tej zgody nie wyraziła, i narusza jej prywatność jedynie w nieznacznym stopniu (art. 43la §4 k.k.w.).

Zgoda osób pełnoletnich nie jest wymogiem bezwzględnym udzielenia skazanemu zezwolenia na odbywanie kary w systemie dozoru elektronicznego ${ }^{12}$. Ustawa przewiduje bowiem sytuacje, w których uzyskanie takiego zezwolenia nie jest konieczne. Niemniej jednak dziwić musi, że potrzeba pozyskania aprobaty na odbywanie kary w systemie dozoru całkowicie abstrahuje od przysługującego skazanemu prawu własności lokalu. Dlaczego bowiem wyłączny właściciel mieszkania ma zostać osadzony $\mathrm{w}$ jednostce penitencjarnej wyłącznie $\mathrm{z}$ tego powodu, że na odbywanie kary w systemie dozoru elektronicznego nie wyraża zgody przykładowo jej zięć, któremu nie przysługują względem powyższego lokalu jakiekolwiek prawa? Ograniczenie w tak szerokim stopniu prawa własności wy-

${ }^{12}$ K. Postulski: Kodeks karny wykonawczy. Komentarz. Warszawa 2017, s. 315. 
daje się w takim przypadku niezasadne, zwłaszcza jeżeli osoba odmawiająca zgody nie została $\mathrm{w}$ żadnym stopniu pokrzywdzona popełnionym przestępstwem, a czasami nawet czerpała $\mathrm{z}$ niego profity.

Trudno niezwłocznie, bez zgłębienia szczegółów i różnych możliwych wariantów, zanegować potrzebę uzyskiwania zezwolenia pełnoletnich domowników. Nie można zanegować wartości, która bez otrzymania takiej aprobaty mogłaby zostać naruszona, to jest prawa do prywatności osób zajmujących taki lokal. Niewątpliwie odbywanie kary w systemie dozoru elektronicznego wiąże się z pewnymi niedogodnościami: wizytą specjalistów w celu sprawdzenia warunków technicznych lokalu, zamontowania sprzętu, telefonów oraz wizyt w razie naruszenia zasad odbywania takiej kary. Z tego też względu w piśmiennictwie podkreślano wręcz, że wymóg uzyskania zezwolenia powinien mieć charakter bezwzględny. Opierał się on na stanowisku, że czynienie jakichkolwiek wyjątków od konieczności pozyskania zgody na odbywanie kary w systemie dozoru elektronicznego jest niezgodne $\mathrm{z}$ art. 77 Konstytucji RP, który nie wspomina o ochronie życia prywatnego $\mathrm{w}$ stopniu znacznym, ale o ochronie $\mathrm{w}$ jakimkolwiek stopniu, a ponadto w myśl Zaleceń Komitetu Ministrów Rady Europy z dnia 19 lutego 2014 r., pkt 6, zastosowanie dozoru elektronicznego oraz określenie jego typu, czasu trwania i sposobów wykonywania powinno uwzględniać prawa i interesy rodziny i innych osób w miejscu zamieszkania oskarżonego lub sprawcy przestępstwa ${ }^{13}$. Stanowisko to można wesprzeć uzasadnieniem, że konkretny lokal staje się w takiej sytuacji miejscem wykonywania kary, co, uwzględniwszy obowiązek pozostawania $\mathrm{w}$ nim skazanego $\mathrm{w}$ określonych porach, nie pozostaje $\mathrm{w}$ końcu bez wpływu na swobody i uprawnienia innych osób tam zamieszkujących ${ }^{14}$.

Jednocześnie trudno tracić z pola widzenia, że przestępstwo, za które dana osoba została skazana, może mieć bardzo różny charakter. O ile zrozumiałe jest, że przy przestępstwach przeciwko rodzinie narażanie domowników na przymusowe ograniczanie prywatności w wyniku udzielenia zgody na odbywanie kary w systemie dozoru elektronicznego pogłębiać może konflikt wywołany przestępstwem, to przy innego rodzaju przestępczości ewentualne naruszenie prywatności nie powinno ustępować prawu własności i wiążącego się z nim prawem do decydowania o przeznaczeniu swojej rzeczy. Z przepisów Kodeksu rodzinnego i opiekuńczego ${ }^{15}$ wynika, że jeżeli prawo do mieszkania przysługuje jednemu

${ }^{13}$ T. SzYmanowski: Nowelizacja prawa karnego wykonawczego - przeglad ważniejszych zagadnień. Pal. 2015, z. 7-8, s. 187.

${ }^{14}$ Por. M. RusineK: Ustawa o dozorze elektronicznym. Warszawa 2010, s. 83-84; I. Zgolíśsi. W: Kodeks karny wykonawczy. Komentarz. Red. J. LACHOwsKi. Warszawa 2016, s. 194.

${ }^{15}$ Ustawa z dnia 25 lutego 1964 r., Dz.U. 2017, poz. 682. 
małżonkowi, drugi małżonek jest uprawniony do korzystania $\mathrm{z}$ tego mieszkania w celu zaspokojenia potrzeb rodziny (art. $28^{1}$ k.r.o.). Tym samym spośród pełnoletnich domowników małżonek również ma prawo do lokalu i potrzeba pozyskania od niego zgody powinna zostać zachowana. W pozostałych przypadkach korzystanie przez pełnoletnie osoby z lokalu mieszkalnego, jeżeli na sprawcy nie ciąży względem nich obowiązek alimentacyjny, odbywa się na zasadzie użyczenia. Takie zaś prawo nie jest skuteczne względem użyczającego między innymi w sytuacji, gdy rzecz stała się mu potrzebna wskutek okoliczności nieprzewidzianych w chwili zawarcia umowy (art. 716 k.c.). Jeżeli więc skazany ma uprawnienia do doprowadzenia domownika do opuszczenia lokalu mieszkalnego stanowiącego jego własność, to ewentualny brak zgody takich osób nie może ograniczać możliwości odbywania kary w systemie dozoru elektronicznego. Obecny stan prawny prowadzi bowiem do niespójnej sytuacji, w której osoba zajmująca lokal mieszkalny może pozbawić skazanego możliwości wolnościowego odbycia bezwzględnej kary pozbawienia wolności, pomimo że jej uprawnienie do zachowania statusu domownika jest całkowicie uzależnione od woli sprawcy. Wydaje się, że taka regulacja k.k.w. w niewystarczającym stopniu uwzględnia prawo własności oraz związane z nim uprawnienia, prowadząc do niespójności systemu prawnego.

Innym obszarem budzącym wątpliwości z punktu widzenia harmonii prawa karnego z innymi dziedzinami prawa jest nakaz opuszczenia lokalu, a konkretnie związane z nim prawo własności. Ustawodawca nie nawiązał w jakimkolwiek zakresie ani do potrzeby przysługiwania takiego uprawnienia sprawcy, ani pokrzywdzonemu. W konsekwencji uważa się, że możliwość orzeczenia takiego nakazu nie jest zależna od prawa własności bądź zawartej umowy cywilnoprawnej, np. najmu ${ }^{16}$, a w konsekwencji adresatem takiego nakazu może stać się wyłączny właściciel bądź współwłaściciel lokalu ${ }^{17}$. Zastosowanie takiego środka nie pozbawia sprawcy jego własności, a jedynie uniemożliwia czasowe faktyczne korzystanie $\mathrm{z}$ niego ${ }^{18}$. W rezultacie taki nakaz nie narusza prawa własności przysługującego sprawcy, ale jedynie w tym prawie ogranicza ${ }^{19}$.

Taki stan rzeczy rodzi jednak określone konsekwencje. W następstwie orzeczenia takiego środka oskarżony będący właścicielem zostaje pozba-

${ }^{16}$ D. SzeleszczuK. W: Kodeks karny. Komentarz. Red. A. GrześKowiaK, K. WiaK. Warszawa 2017, s. 371.

17 A. ZlóŁKowsKa. W: Kodeks karny. Komentarz. Red. V. KonarsKa-WrzoseK. Warszawa 2016, s. 268-269.

${ }^{18}$ R.A. Stefański. W: Kodeks karny. Komentarz. Red. IDEM. Warszawa 2012, s. 376; podobnie IDEM: Nowe środki probacyjne. Prok. i Pr. 2006, z.4, s. 28.

19 Tak J. Skupiński, J. MierzwińsKa-Lorencka. W: Kodeks karny. Komentarz. Red. R.A. STEFAŃSKi. Warszawa 2012, s. 541-542. 
wiony jedynie możliwości korzystania z lokalu, a nie możliwości rozporządzania nim ${ }^{20}$. Oznacza to, że sprawca lokal może sprzedać lub w inny sposób zdecydować o jego przeznaczeniu ${ }^{21}$. Jest uprawniony do rozwiązania umowy o dostarczenie energii elektrycznej i gazu, a pokrzywdzony, który pozostał w mieszkaniu, nie ma możliwości zawarcia odpowiednich umów ${ }^{22}$. Tym samym trzeba zadać pytanie, czy ustawodawca powinien stosować nakaz opuszczenia lokalu wobec wyłącznego właściciela lokalu mieszkalnego, skoro system prawny pozbawił skazanego tylko pewnego wycinka korzystania z prawa własności, nie pozbawiając go całej gamy uprawnień, z których skorzystanie może być znacząco niekorzystne dla pokrzywdzonego. Na tym zaś prawodawcy nie powinno zależeć, a w konsekwencji system powinien cechować się w tym zakresie większą spójnością, tj. pozbawiać skazanego całości uprawnień względem lokalu w okresie obowiązywania nakazu bądź przynajmniej wprowadzać konieczność uzyskiwania wcześniejszej zgody od pokrzywdzonego na orzeczenie takiego środka. Jeżeli bowiem wówczas sprawca utrudniałby ofierze późniejsze egzystowanie, możliwe byłoby stwierdzenie, że pokrzywdzony, jako osoba pozostająca w pobliżu sprawcy i znająca go najlepiej, mógł mieć tego świadomość, skoro więc zgodził się na orzeczenie takiego nakazu, winien ponieść tego konsekwencje. W aktualnym stanie prawnym ofiara nie musi być pytana przez sąd o zgodę przed orzeczeniem takiego środka, a konsekwencje tejże decyzji przychodzi ponosić właśnie jej.

Potrzeba szerszego respektowania przez prawo karne zasad przewidzianych $\mathrm{w}$ innych gałęziach prawa objawia się również w konieczności respektowania praw i wolności przydanych w nich obywatelom. Tytułem przykładu - nikogo nie dziwi, że po odprowadzeniu obowiązkowych składek osoby wykonujące pracę zarobkową otrzymują, zwykle co miesiąc, całe przypadające im wynagrodzenie do swojej dyspozycji. Państwo nie wykazuje się w tym zakresie nadmierną opiekuńczością i nie wydziela co kilka dni bądź nawet codziennie proporcjonalnej części wynagrodzenia. Osoba niegospodarna, która wyda przedwcześnie całą otrzymaną kwotę, będzie musiała $\mathrm{w}$ dalszym okresie samodzielnie radzić sobie $\mathrm{z}$ tym problemem. Może być to zadanie trudne i choć zdarza się niejednemu, państwo nie wpada na pomysł przymuszania obywateli do oszczędzania.

Trudno zaakceptować, że ustawodawca postanowił wolności tej pozbawić osoby przebywające $\mathrm{w}$ jednostkach penitencjarnych, wykonują-

${ }^{20}$ A. SAKowicz. W: System prawa karnego. T. 6: Kary i środki karne. Poddanie sprawcy próbie. Red. M. MelEzinI. Warszawa 2010, s. 570-571.

${ }^{21}$ A. KowalczuK: Obowiązek opuszczenia lokalu zajmowanego wspólnie z pokrzywdzonym. Prok. i Pr. 2009, z. 7-8, s. 141.

${ }^{22}$ S. SPUREK: Izolacja sprawcy od ofiary. Instrumenty przeciwdziatania przemocy $w$ rodzinie. Warszawa 2013, s. 256-257. 
ce w czasie osadzenia pracę zarobkową. Zgodnie z art. $126 \S 1$ k.k.w. ze środków pieniężnych otrzymywanych przez skazanego, z wyjątkiem środków, o których mowa w art. 113 § 6 pkt 1-3, środki do wysokości jednego przeciętnego miesięcznego wynagrodzenia pracowników gromadzi się i zachowuje do przekazania skazanemu w chwili jego zwolnienia $\mathrm{z}$ zakładu karnego, z przeznaczeniem na przejazd do miejsca zamieszkania i na utrzymanie; ze środków tych nie prowadzi się egzekucji. Dodatkowo w myśl $\$ 2$ przywołanego przepisu gromadzeniu podlega: 50\% kwoty zdeponowanej przez skazanego przy przyjęciu do zakładu karnego, jednak nie więcej niż kwota odpowiadająca wysokości jednego przeciętnego miesięcznego wynagrodzenia pracowników (pkt 1); 50\% z przypadającego skazanemu miesięcznie wynagrodzenia za pracę po odliczeniu zaliczki na podatek dochodowy od osób fizycznych, jednak nie więcej niż kwota stanowiąca 4\% jednego przeciętnego miesięcznego wynagrodzenia pracowników (pkt 2); 50\% każdego z wpływów pieniężnych skazanego niewymienionych w pkt. 1 i 2 , jednak nie więcej niż kwota stanowiąca $4 \%$ jednego przeciętnego miesięcznego wynagrodzenia pracowników.

Wskazane powyżej potrącenia stanowią tzw. żelazną kasę, której zasobność nie może przekraczać jednego przeciętnego miesięcznego wynagrodzenia pracowników ${ }^{23}$. W doktrynie zauważano, że przepis ten $\mathrm{z}$ jednej strony ogranicza prawa skazanego, ale z drugiej zapewnia mu możliwość utrzymania się po opuszczeniu zakładu karnego poprzez gromadzenie tzw. wypiski ${ }^{24}$. Ostatecznie przepis ten spotykał się $\mathrm{z}$ aprobatą. Wskazywano w szczególności, że zgromadzenie, najlepiej w maksymalnej wysokości, środków finansowych jest ważnym elementem przygotowania skazanego do zwolnienia oraz ogranicza wydatki Funduszu Pomocy Pokrzywdzonym oraz Pomocy Postpenitencjarnejej. Nie kwestionując znaczenia zabezpieczenia finansowego skazanego po wyjściu na wolność, trudno nie dostrzegać, jak niewychowawcze może być przymuszanie osadzonego do oszczędzania. „Żelazna kasa” nie powstaje bowiem z objęcia skazanego opieką socjalną w momencie wyjścia na wolność, a z zobligowania osadzonych wykonujących pracę zarobkową i otrzymujących z tego tytułu wynagrodzenie do odkładania pieniędzy na przyszłość. Jak dobrze by to nie brzmiało, w realnym życiu tak się nie dzieje. Nakazuje to zadać pytanie, czy państwo, realizujące w tym zakresie silnie opiekuńcze zadania, nie pogłębia u skazanych syndromu wyuczonej bezradności, doprowadzając do pewnego automatyzmu, konformistycznych postaw i utraty

${ }^{23}$ S. Lelental: Kodeks karny wykonawczy. Komentarz. Warszawa 2014, s. 415.

${ }^{24}$ K. Postulski. W: Kodeks karny wykonawczy. Komentarz. Red. J. LACHOwsKi. Warszawa 2016, s. 528.

${ }^{25}$ K. Postulski: Kodeks karny wykonawczy..., s. 663. 
poczucia odpowiedzialności ${ }^{26}$. Przymusowe odprowadzanie części wynagrodzenia prowadzi bowiem do sprzecznej z zasadami wolnorynkowymi sytuacji, w której państwo postanawia zacząć oszczędzać za dorosłego człowieka. Jeżeli ktoś nauczy się w taki sposób żyć w więzieniu, na wolności może być mu bardzo trudno.

Prawo karne, choć ze swej istoty represyjne, nie powinno ograniczać wolności skazanych w sposób nadmierny, ograniczając swobodę podejmowania decyzji pozostającej $\mathrm{w}$ ich autonomii. Tak jak nie powinno nakazywać oszczędzania dorosłym ludziom, tak samo nie powinno nadmiernie ingerować $\mathrm{w}$ prawa pokrzywdzonych. Powracając do nakazu opuszczenia lokalu, warto podkreślić, że zasadność orzeczenia takiego środka bez zgody osoby pokrzywdzonej jest co najmniej wątpliwa. Tymczasem ofiara przestępstwa może być uzależniona ekonomicznie od sprawcy, a na samodzielne pozostawanie w lokalu zwyczajnie może jej nie być stać. Dodatkowo państwo nie może ingerować w życie prywatne obywateli, nawet jeśli uważa, że określona relacja nie jest pożądana. Tak jak prokurator nie może złożyć pozwu o rozwód lub separację za stronę, nie powinien pozostawać $\mathrm{w}$ uprawnieniu do arbitralnego zakazywania wspólnego zamieszkiwania sprawcy z orzeczonym nakazem opuszczenia lokalu i pokrzywdzonemu. Tym samym stanowczo należy podkreślić, że utrzymywanie takiego stanu rzeczy nie jest korzystne.

Zachowanie spójności systemu prawa jest o tyle trudne, że z jednej strony konieczne jest harmonijne odczytywanie wzorców dla poszczególnych zagadnień, z poszanowaniem dla wartości stojących u ich podłoża, a z drugiej strony dążenie do jednolitości nie może zaprzepaścić wypełnienia funkcji stawianych przed różnymi gałęziami prawa. Zakreślone powyżej przypadki niedostrzegania w wystarczającym stopniu norm cywilnoprawnych przez prawo karne nie stanęłyby w żadnym stopniu na przeszkodzie realizacji zadań tej ostatniej dziedzinie prawa. Pytanie jednak co stałoby się w sytuacji odwrotnej. Nietrudno jest wyobrazić sobie sytuację, w której odczytanie określonej normy zgodnie z regułami prawa cywilnego zanegowałoby prawnokarny sens tej instytucji. Ustawodawca stara się bowiem czasami tak szeroko uwzględniać reguły obowiązujące w stosunku podstawowym, usytuowane poza zakresem czynów zabronionych pod groźbą kary, że pod znakiem zapytania stawia możliwość należytego wypełnienia funkcji przypisanych prawu karnemu.

Od wielu lat nie budzi wątpliwości potrzeba autonomicznego wykładania pewnych pojęć w prawie karnym. Wiadomo na przykład, że rzecz

${ }^{26}$ Por. R. Pomianowski: Niektóre implikacje teorii wyuczonej bezradności do pracy penitencjarnej - o potrzebie profesjonalizacji wykonywania kary pozbawienia wolności. „Przegląd Więziennictwa Polskiego" 1997, nr 13, s. 27 i nast.; M. CıоseK: Izolacja więzienna. Wybrane aspekty izolacji więziennej w percepcji więźniów i personelu. Gdańsk 1993, s. 36 i nast. 
ruchoma, która może stać się przedmiotem kradzieży, musi być w prawie karnym rozumiana inaczej niż $\mathrm{w}$ prawie cywilnym. Wynika to nie tylko z wyjątkowo wąskiego rozumienia „rzeczy ruchomej” w cywilistyce, lecz także wprowadzenia do tzw. słowniczka wyrażeń ustawowych definicji tego pojęcia ${ }^{27}$. W przeciwnym wypadku kradzież bramy z ogrodzenia nie mogłaby stanowić przedmiotu prawnokarnej oceny, gdyż zgodnie z art. 47 $\$ 1$ k.c. część składowa rzeczy nie może być odrębnym przedmiotem własności i innych praw rzeczowych. Zasadniczo potrzeba dokonania własnej wykładni pojęć na obszarze różnych gałęzi prawa nie budzi większych wątpliwości w tych obszarach, w których ustawodawca zdecydował się na wprowadzenie definicji legalnych. Jest to bowiem sygnał, że konieczne jest odrębne zdefiniowanie konkretnego pojęcia. Podobna sytuacja ma wszakże miejsce przy dokumencie, którego definicja jest istotna nie tylko dla szeroko rozumianego prawa karnego, ale również dla prawa karnego procesowego, kryminalistyki, procesu cywilnego czy też postępowania administracyjnego oraz sądowoadministracyjnego ${ }^{28}$. Jak słusznie wskazał P. Ochman, w każdej z tych dziedzin ma ono do spełnienia odrębne funkcje - w obszarze procedury cywilnej czy administracyjnej wyróżnienie pojęcia dokumentu następuje ze względu na konieczność przydania mu określonej mocy dowodowej, w procesie karnym dokument traktowany jest jako dowód rzeczowy, w kryminalistyce rozchodzi się o rzeczowe środki dowodowe wyróżniające się od innych posiadaniem treści pisemnej jako elementu składowego ${ }^{29}$. Istnieje jednak wiele obszarów, które nie cechują się podobną konsekwencją $\mathrm{w}$ dostrzeganiu odmiennych zadań stawianych przed prawem karnym, a co za tym idzie - potrzebą dokonania odrębnej wykładni pomimo zanegowania w innym wypadku funkcji prawa karnego.

Przykładem takiego stanu rzeczy może stać się orzekanie pomiędzy współdziałającymi solidarnego obowiązku naprawienia szkody. W myśl art. 441 § 1 k.c. jeżeli kilka osób ponosi odpowiedzialność za szkodę wyrządzoną czynem niedozwolonym, ich odpowiedzialność jest solidarna. Oznacza to, że w prawie cywilnym w ramach odpowiedzialności deliktowej dłużnicy odpowiadają za wyrządzoną szkodę solidarnie, a przepis ten ma charakter bezwzględnie wiążący ${ }^{30}$. Oznacza to, że w przeciwieństwie

${ }^{27}$ M. Dąbrowska-Kardas, P. Kardas. W: Kodeks karny. Część szczególna. T. III: Komentarz do art. 278-363. Red. A. Zoll. Warszawa 2016, LEX/el.

${ }^{28}$ Zob. J. PiórkowsKa-Fleger: Fatsz dokumentu $w$ polskim prawie karnym. Kraków 2004, s. 99 i nast.

${ }^{29}$ Tak P. Ochman: Spór o pojęcie dokumentu $w$ prawie karnym. Prok. i Pr. 2009, z. 1, s. 21-22 wraz z przywołaną tam literaturą.

${ }^{30}$ Tak A. OlejniczaK. W: Kodeks cywilny. Komentarz. T. III. Red. A. Kidyba. Warszawa 2014, LEX/el. 
do art. $137 \S 1$ Kodeksu zobowiązań, który dopuszczał udowadnianie, kto w jakim stopniu przyczynił się do wywołania szkody, obecnie obowiązujący przepis art. $441 \S 1$ k.c. nie przewiduje wyjątków od zasady solidarnej odpowiedzialności kilku osób, które wyrządziły szkodę czynem niedozwolonym - nie jest wiec dopuszczalne dowodzenie wobec poszkodowanego, że jedna $\mathrm{z}$ tych osób przyczyniła się do szkody w mniejszym stopniu niż inna ${ }^{31}$.

Przeniesienie powyższej zasady na grunt prawa karnego od dawna budziło wiele wątpliwości. Wskazywano w szczególności, że z uwagi na zasadę indywidualizacji odpowiedzialności karnej nie jest możliwe powstanie odpowiedzialności solidarnej opartej na podstawach karnoprawnych ${ }^{32}$. Jakkolwiek przyjęcie solidarnej odpowiedzialności byłoby najkorzystniejsze dla pokrzywdzonego, który zachowałby dowolność w wyborze osoby, od której mógłby dochodzić nawet pełnej wartości szkody, to jednak taka koncepcja nie daje się pogodzić z zasadą indywidualizacji odpowiedzialności i dyrektywą winy ${ }^{33}$.

W judykaturze dominujące poparcie uzyskało jednak inne stanowisko. W uchwale z dnia 13 grudnia 2000 r. Sąd Najwyższy przyjął, że orzeczenie środka karnego, przewidzianego w art. 46 \$1 k.k., dopuszczalne jest również $\mathrm{w}$ postaci solidarnego zobowiązania współsprawców przestępstwa do naprawienia wyrządzonej szkody w całości albo w części ${ }^{34}$. W uzasadnieniu SN podkreślił, że jakkolwiek orzeczenie środka karnego jest dopuszczalne nie tylko w postaci solidarnego zobowiązania współsprawców do naprawienia wyrządzonej przestępstwem szkody, to jednak mając na względzie potrzebę zwiększenia ochrony w procesie karnym interesów pokrzywdzonego, nie ma przeszkód prawnych, aby w wypadku spowodowania szkody przestępstwem dokonanym w warunkach współsprawstwa orzec obowiązek solidarnego naprawienia wyrządzonej szkody - w całości albo w części. Stanowisko to spotkało się z akceptacją w doktrynie ${ }^{35}$, zwłaszcza po 1 lipca 2015 r., z którym to dniem zmieniono treść art. 46 $\S 1$ k.k. poprzez wskazanie, że przy orzekaniu obowiązku naprawienia szkody należy stosować przepisy prawa cywilnego. $\mathrm{Z}$ nowelizacją tą korespondowała zmiana charakteru art. $46 \$ 1$ k.k. ze środka karnego, pełniącego w dużej mierze funkcje penalne, w środek kompensacyjny, zmie-

${ }^{31}$ Wyrok SN z dnia 2 grudnia 1970 r., II CR 542/70, OSNC 1971, z. 9, poz. 153.

32 Tak Z. GosTYŃskI: Obowiazek naprawienia szkody w nowym ustawodawstwie karnym. Kraków 1999, s. 196-197.

33 J. LachowsKi, T. Oczкоwsкi: Obowiązek naprawienia szkody jako środek karny. Prok. i Pr. 2007, z. 9, s. 52-53.

${ }^{34}$ Uchwała SN z dnia 13 grudnia 2000 r., I KZP 40/00, OSNKW 2001, z. 1-2, poz. 2.

${ }^{35}$ K. Szczucki. W: Kodeks karny. Część ogólna. Komentarz. Art. 1-116. Red. M. KRóLIKOWSKI, R. ZAWŁOCKI, s. 778. 
rzający do indemnizacji. W konsekwencji w doktrynie podkreślano, że wobec powyższych zmian w stanie ustawodawstwa nie powinno budzić wątpliwości, że w razie wyrządzenia szkody przez kilka osób, ich odpowiedzialność będzie miała charakter solidarny ${ }^{36}$.

Co ciekawe, pogląd o możliwości solidarnego zobowiązywania współdziałających do naprawienia szkody zaczęto przenosić również na grunt zobowiązań probacyjnych. Początkowo wskazywano, że nałożenie na oskarżonego obowiązku naprawienia szkody $\mathrm{w}$ ramach warunkowego zawieszenia wykonania kary musi mieć charakter jego osobistego obciążenia, a obowiązek restytucyjny nie może mieć charakteru solidarnego, gdyż to indywidualna postawa oskarżonego w odniesieniu do nałożonych obowiązków stanowi jedno z istotnych kryteriów oceny przebiegu okresu próby. Tym samym wykonania obowiązku nałożonego na oskarżonego nie można uzależniać od zachowania się innej osoby oskarżonej, gdyż uniemożliwia to należytą ocenę postawy konkretnego oskarżonego wobec obowiązku, który ciąży na nim osobiście ${ }^{37}$. Później jednak przeważyło zdanie, w myśl którego taki sposób nałożenia zobowiązania probacyjnego jest możliwy ${ }^{38}$. Pogląd ten znalazł akceptację w części doktryny wskazującej, że do orzeczonego tytułem środka probacyjnego obowiązku naprawienia szkody nałożonego na kilku skazanych należy stosować odpowiednio przepisy Kodeksu cywilnego dotyczące zobowiązań solidarnych, zaś niewykonanie obowiązku wyrównania szkody przez skazanego nie będzie stanowiło podstawy do zarządzenia wykonania kary warunkowo zawieszonej wobec niego wtedy, gdy szkoda ta została już wyrównana w całości przez innego ze skazanych ${ }^{39}$. W literaturze zgłaszano wątpliwości co do takiego rozwiązania, wskazując, że nie ma on bowiem charakteru środka kompensacyjnego, stanowi o możliwości nałożenia tego obowiązku w całości lub w części, zrywając z charakterystyczną dla prawa cywilnego zasadą pełnej kompensaty szkody ${ }^{40}$. Podkreślano w szczególności, że zobowiązania probacyjne orzekane w ramach zobowiązań probacyjnych powinny mieć charakter osobistego obciążenia skazanego ${ }^{41}$.

${ }^{36}$ D. SzeleszCZuK. W: Kodeks karny. Komentarz. Red. A. GrześKowiaK, K. WiAK. Warszawa 2018, s. 460; M. SzewczyK, M. JaKubowski, M. IwaŃski. W: Kodeks karny. Część ogólna. T. I: Komentarz do art. 1-52. Red. W. Wróbel, A. Zoll. Warszawa 2016, s. 904-905.

${ }^{37}$ Tak wyrok SA w Katowicach z dnia 24 marca 2011 r., II AKa 49/11, LEX nr 846493.

${ }^{38}$ Tak wyrok SA w Katowicach z dnia 11 grudnia 2015 r., II AKa 352/15, Biul.SAKa 2016/2/4.

${ }^{39}$ S. Hypś. W: Kodeks karny. Komentarz. Red. A. GrześKowiaK, K. WiAK. Warszawa 2018, s. 535.

${ }^{40}$ J. Lachowski. W: Kodeks karny. Część ogólna. Komentarz Art. 1-116. Red. M. KróliKowsKI, R. ZaWŁocKI, s. 1006.

${ }^{41}$ A. Zoll. W: Kodeks karna. Część Ogólna. T. I: Komentarz do art. 53-116. Red. W. Wróbel, A. Zoll. Warszawa 2016, s. 326. 
Rozważając taką możliwość, sąd winien mieć na uwadze, iż nakładane zobowiązania winny wiązać się z popełnionym przestępstwem ${ }^{42}$, choć czasami wykazanie $\mathrm{w}$ tym zakresie ścisłego związku nie jest możliwe (tak przykładowo przy zobowiązaniu do wykonywania pracy zarobkowej) ${ }^{43}$. Ich głównym celem winno być wspieranie zachowania skazanego w okresie próby $\mathrm{w}$ taki sposób, aby nie popełnił on ponownie przestępstwa. Konkludując, dopuszczenie obowiązującej w prawie cywilnym zasady solidarnej odpowiedzialności za czyn niedozwolony w prawie karnym, zwłaszcza przy zobowiązaniach probacyjnych, stawiałoby pod znakiem zapytania możliwość wypełnienia funkcji nadawanych tym środkom, a więc zweryfikowania, czy sformułowana dla sprawcy prognoza kryminologiczno-społeczna okazała się prawdziwa.

Analogiczna sytuacja ma zresztą miejsce przy zobowiązaniu do naprawienia szkody. W prawie cywilnym poszkodowany może uzyskać tytuł wykonawczy uprawniający go do przymusowej egzekucji z momentem uprawomocnienia się orzeczenia sądu, choć czasami jest to możliwe nawet wcześniej, gdy decyzji takiej został nadany rygor natychmiastowej wykonalności (por. art. 776 k.p.c. w zw. z art. $777 \S 1$ pkt 1 k.p.c.). Tymczasem w prawie karnym, w przeciwieństwie do środka kompensacyjnego z art. $46 \S 1$ k.k., nie będzie to moment uprawomocnienia się orzeczenia, a upływ terminu zakreślonego przez sąd do wywiązania się $\mathrm{z}$ tego obowiązku ${ }^{44}$. Przyjęcie odmiennej koncepcji, tj. momentu uprawomocnienia się orzeczenia sądu, pozbawiałoby skazanego możliwości wykazania się dobrowolnością w naprawieniu szkody, a więc weryfikatora słuszności sformułowanej prognozy kryminologiczno-społecznej. Dochodzi więc do sytuacji, w której przy orzeczeniu obowiązku restytucyjnego pokrzywdzony jest uprawniony do przymusowego dochodzenia przysługującej mu należności później, aniżeli miałoby to miejsce w razie uzyskania tytułu w postępowaniu cywilnym. Nie jest to zapewne ko-

42 Zob. wyrok SN z dnia 6 lutego 1973 r., V KRN 582/71, OSNKW 1973, z. 11, poz. 139, s. 23-24 (nałożenie obowiązków powinno pozostawać w związku z takim zachowaniem się lub stanem spowodowanym przez sprawcę, które należą do istoty czynu mu przypisanego albo stanowią wywołane tym czynem skutki, a w każdym razie powinno mieć na względzie potrzebę profilaktycznego oddziaływania tego środka wychowawczego na sprawcę); wyrok SN z dnia 6 listopada 1970 r., V KRN 419/70, OSNKW 1971, z. 2, poz. 26, s. 33-34 (nałożenie obowiązku powstrzymywania się od nadużywania alkoholu może być uzasadnione tylko wtedy, gdy w danej sprawie zostanie ustalone, że sprawca nadużywał alkoholu przed popełnieniem przestępstwa albo wtedy, gdy popełnił on przestępstwo w stanie nietrzeźwości, poprzedzonej nadużyciem alkoholu); J. SKUPIŃsKI: Warunkowe skazanie w prawie polskim i na tle porównawczym. Warszawa 1992, s. 289-290.

${ }^{43}$ Por. ibidem, s. 291.

44 Zob. uchwała SN z dnia 24 maja 2005 r., I KZP 17/05, OSNKW 2005, z. 7-8, poz. 59 , s. 10 i nast. 
rzystne dla ofiary przestępstwa, ale jest to jedyne racjonalne rozwiązania w punktu widzenia zasad stawianych przed prawem karnym.

Podział systemu prawnego na gałęzie prawa ma w dużej mierze charakter umowny, a przedmioty ich regulacji wzajemnie się przenikają. Zmiany cywilizacyjne oraz postępująca skłonność do uszczegóławiania przepisów regulujących już niemal wszystkie dziedziny życia ${ }^{45}$ sprawiają, że prawo karne dotyka coraz to nowych obszarów. Nie pozostaje to jednak bez wpływu na pogłębianie się konotacji pomiędzy prawem karnym a innymi gałęziami, zwłaszcza prawem cywilnym ${ }^{46}$. W ocenie wielu kontrolę ustawodawcy nad zasięgiem kryminalizacji skuteczniej zabezpiecza kodyfikacja - jeśli nie całości, to przynajmniej większej części tej dziedziny prawa ${ }^{47}$. Wrastanie norm prawnych w coraz to nowe obszary siłą rzeczy musi rodzić obawy o brak spójności pomiędzy poszczególnymi regulacjami bądź też, w razie silnego dążenia do wpisania się przez prawo karne w normy prawne regulujące określoną dziedzinę życia, do zanegowania zdolności osiaggania przez prawo karne funkcji stawianych tejże dziedzinie prawa.

System prawny powinien być spójny, ale konieczne jest również respektowanie zadań formułowanych poszczególnym dziedzinom prawa tak, aby z jednej strony umożliwić im należyte wypełnianie przydanych im funkcji, a z drugiej - aby nie tworzyć ograniczeń niepotrzebnych, które nie znajdują usprawiedliwienia na gruncie gałęzi regulujących daną sferę życia społecznego, a jednocześnie nie są niezbędne do realizacji celów prawa karnego. Jest raczej rzeczą oczywistą, że unikanie niezamierzonych sprzeczności w prawie wymaga wiele troski i wysiłku od prawodaw$\mathrm{cy}^{48}$. Naturalnie większość ze wskazanych powyżej niespójności nie ma charakteru sprzeczności logicznej, tylko niedostrzegania w stopniu dostatecznym reguł rządzących się innymi gałęziami prawa. Rozstrzygając o niespójności, brać należy pod uwagę nie tylko - i nawet nie przede wszystkim - okoliczności techniczne, ale sytuację w całej jej złożoności - prawnej, moralnej, politycznej, ekonomicznej czy socjologicznej ${ }^{49}$.

${ }^{45}$ Już od dawna zauważano tendencję do obejmowania zasięgiem kryminalizacji kolejnych zachowań związanych z życiem gospodarczym - zob. O. GóRnIoK: Przestępstwa gospodarcze (rozdziat XXX kodeksu karnego). Warszawa 1981, s. 195.

46 Takie zachowania nie są oparte na zasadach etyki społecznej czy norm kulturowych, a na stosunkach społecznych, regulowanych przez inne gałęzie prawa aniżeli prawo karne - z tego też względu ich karnoprawna ocena wymaga odniesienia się, chociażby pośrednio, do istniejących już norm. Zob. S. ŻóŁteк: Prawo karne gospodarcze $w$ aspekcie zasady subsydiarności. Warszawa 2009, s. 167.

${ }^{47}$ Tak O. GóRNIOK: O trzech wariantach prawnokarnej ochrony obrotu gospodarczego. PrzSejm1993, nr 9, s. 8.

${ }^{48}$ L.L. Fuller: Moralność prawa. Warszawa 2004, s. 55.

${ }^{49}$ Ibidem, s. 59. 
Wydaje się, że ustawodawcy czasami brakuje dostrzeżenia owej złożoności problemu.

\section{Bibliografia}

\section{Literatura}

Cı́seK M.: Izolacja więzienna. Wybrane aspekty izolacji więziennej $w$ percepcji więźniów i personelu. Gdańsk 1993.

Dukiet-Nagórska T.: Prawo karne. Część ogólna, szczególna i wojskowa. Warszawa 2016.

Fuller L.L.: Moralność prawa. Warszawa 2004.

GosTYŃsKI Z.: Obowiązek naprawienia szkody w nowym ustawodawstwie karnym. Kraków 1999.

GóRnIOK O.: Przestępstwa gospodarcze (rozdziat XXX kodeksu karnego). Warszawa 1981.

GóRNIOK O.: Znaczenie subsydiarności prawa karnego w jego interpretacji. PiP 2007, Z. 5.

GóRNIOK O.: O trzech wariantach prawnokarnej ochrony obrotu gospodarczego. PrzSejm1993, nr 9.

Kodeks cywilny. T. II: Komentarz do artykułów 450-1088. Red. K. PietrzyKowsKi. Warszawa 2005.

Kodeks cywilny. Komentarz. T. III. Red. A. KidyBA. Warszawa 2014, LEX/el.

Kodeks karny. Część ogólna. T. I: Komentarz do art. 1-52. Red. W. WróBel, A. Zoll. Warszawa 2016.

Kodeks karny. Część ogólna. Komentarz. Art. 1-116. Red. M. KróliKowsKi, R. ZawıOCKI. Warszawa 2017.

Kodeks karny. Część szczególna. T. III: Komentarz do art. 278-363. Red. A. ZolL. Warszawa 2016, LEX/el.

Kodeks karny. Komentarz. Red. A. GrześKowiaK, K. WiaK. Warszawa 2017.

Kodeks karny. Komentarz. Red. R.A. STEFAŃsKI. Warszawa 2012.

Kodeks karny wykonawczy. Komentarz. Red. J. LACHOwsKi. Warszawa 2016.

Konarska-Wrzosek V.: Kodeks karny. Komentarz. Warszawa 2016.

KowalczuK A.: Obowiązek opuszczenia lokalu zajmowanego wspólnie z pokrzywdzonym. Prok. i Pr. 2009, z. 7-8.

Królikowski M., ZawŁocki R.: Prawo karne. Warszawa 2015.

LACHOWSKI J., OCzKOWsKi T.: Obowiązek naprawienia szkody jako środek karny. Prok. i Pr. 2007, z. 9.

LANG W., WróBlewsKi J., ZawadzKi S.: Teoria państwa i prawa. Warszawa 1979.

LELENTAL L.: Kodeks karny wykonawczy. Komentarz. Warszawa 2014.

Nowacki J., Tobor Z.: Wstęp do prawoznawstwa. Kraków 2000.

Ochman P.: Spór o pojęcie dokumentu w prawie karnym. Prok. i Pr. 2009, z. 1.

PiórkowsKa-Flieger J.: Fatsz dokumentu $w$ polskim prawie karnym. Kraków 2004. 
Pomianowski R.: Niektóre implikacje teorii wyuczonej bezradności do pracy penitencjarnej - o potrzebie profesjonalizacji wykonywania kary pozbawienia wolności. „Przegląd Więziennictwa Polskiego” 1997, nr 13.

POSTUlSKI K.: Kodeks karny wykonawczy. Komentarz. Warszawa 2017.

Problemy wymiaru sprawiedliwości karnej. Księga jubileuszowa Profesora Jana Skupińskiego. Red. A. BŁAchnio-Parzych. Warszawa 2013

RusineK M.: Ustawa o dozorze elektronicznym. Warszawa 2010.

Sienkiewicz Z., Кокот R.: Populizm penalny $i$ jego przejawy $w$ Polsce. Wrocław 2009.

SKUPIŃSKI J.: Warunkowe skazanie $w$ prawie polskim $i$ na tle porównawczym. Warszawa 1992.

SPUREK S.: Izolacja sprawcy od ofiary. Instrumenty przeciwdziatania przemocy $w$ rodzinie. Warszawa 2013.

Stefański R.A.: Nowe środki probacyjne. Prok. i Pr. 2006, z. 4.

System prawa karnego. T. 6: Kary i środki karne. Poddanie sprawcy próbie. Red. M. MelezINI. Warszawa 2010.

SzYmANowski T.: Nowelizacja prawa karnego wykonawczego - przeglad ważniejszych zagadnień. Pal. 2015, z. 7-8.

Wróbel W., Zoll A.: Polskie prawo karne. Część ogólna. Kraków 2010

ŻóŁTeK S.: Prawo karne gospodarcze $w$ aspekcie zasady subsydiarności. Warszawa 2009.

\section{Orzecznictwo}

Uchwała SN z dnia 13 grudnia 2000 r., I KZP 40/00, OSNKW 2001, z. 1-2, poz. 2.

Uchwała SN z dnia 24 maja 2005 r., I KZP 17/05, OSNKW 2005, z. 7-8, poz. 59. Wyrok SN z dnia 6 listopada 1970 r., V KRN 419/70, OSNKW 1971, z. 2, poz. 26. Wyrok SN z dnia 2 grudnia 1970 r, II CR 542/70, OSNC 1971, z. 9, poz. 153. Wyrok SN z dnia 6 lutego 1973 r., V KRN 582/71, OSNKW 1973, z. 11, poz. 139. Wyrok SA w Katowicach z dnia 24 marca 2011 r., II AKa 49/11, LEX nr 846493. Wyrok SA w Katowicach z dnia 11 grudnia 2015 r., II AKa 352/15, Biul.SAKa 2016/2/4. 